JAMALI - Jurnal Abdimas Madani dan Lestari

Vol. 01, Issue. 01, Maret 2019, Hal 1-17

(e-ISSN: - ; p-ISSN: - )

https://journal.uii.ac.id/JAMALI

\title{
Pelatihan Pengembangan Organisasi Kepemudaan Satuan Pemuda-Pemudi Dirgantara Asri (SAPDA)
}

\author{
Ali Mahmud Ashshiddiqi \\ Fakultas Psikologi dan Ilmu Sosial Budaya, Universitas Islam Indonesia \\ Email: ali.ma@uii.ac.id
}

\begin{abstract}
ABSTRAK
Satuan Pemuda - Pemudi Dirgantara Asri (SAPDA) adalah organisasi kepemudaan yang yang sedang berkembang di Perumahan Dirgantara Asri, Jragung, Jogotirto, Berbah, Sleman, Yogyakarta. Organisasi ini memiliki peran kontribusi yang sangat besar dan signifikan. Organisasi SAPDA memiliki masalah efektifitas organisasi terkait dengan masalah: kedisiplinan waktu, ketertiban administrasi, soliditas tim, etika bersikap dan bertindak, dan masalah-masalah personal lainnya. Berdasarkan latar belakang kondisi tersebut, kegiatan pengabdian masyarakat ini dilakukan untuk meningkatkan efektifitas organisasi, mengokohkan eksistensi organisasi sebagai elemen sosial yang mewadahi aktualisasi peran pemuda/pemudi dan subjek esensial dari proses regenerasi di perumahan Dirgantara Asri.

Pengabdian masyarakat ini mengambil format pelatihan pengembangan organisasi yang terdiri dari tiga kegiatan yang berkelanjutan, yaitu: focus group discussion (FGD), outbound, dan pelatihan. Pelatihan pengembangan organisasi kepemudaan disini menyasar kepada setiap individu anggota SAPDA maupun seluruh anggota SAPDA sebagai kelompok. Pelatihan berorientasi kepada peningkatan motivasi berorganisasi melalui kegiatan FGD, dan penguatan kapasitas team building melalui kegiatan outbound. Sebagai penguatan terhadap hasil FGD dan outbond, kegiatan dilanjutkan dengan pelatihan pengembangan organisasi. Secara menyeluruh, tiga rangkaian kegiatan pengabdian disusun secara sistematis-interkonektif dan memiliki relevansi bagi kebutuhan atau permasalahan yang dihadapi SAPDA sebagai intitusi mitra.

Tiga kegiatan pengabdian memenuhi asas keberlanjutan dan berorientasi pada peningkatan efektifitas organisasi SAPDA. FGD mendorong muncunya self-awareness dan sensitifitas peserta terhadap organisasi, kesadaran akan persoalan-persoalan di dalam organisasi dan pentingnya motivasi berorganisasi. Outbound memiliki pengaruh terhadap kesadaran bersama tentang pentingnya kekuatan-kekuatan team building dalam organisasi. Sedangkan pelatihan memberikan penguatan-penguatan psikologis dan menggarisbawahi nilai-nilai utama yang terkandung dalam dua kegiatan sebelumnya. Berdasarkan hasil-hasil kegiatan ini, pengabdi memberikan saran-saran kepada SAPDA sendiri dan kegiatan-kegiatan pengabdian lain yang berorientasi kepada pengembangan organisasi kepemudaan.
\end{abstract}

Kata Kunci: focus group discussion (FGD), outbound, pelatihan, Satuan Pemuda-Pemudi Dirgantara Asri (SAPDA)

\section{PENDAHULUAN}

Perumahan Dirgantara Asri dalam sejarahnya termasuk perumahan yang sudah berdiri lama tapi mengalami perkembangan yang cukup lambat terutama secara fisik. Kondisi infrastruktur perumahan ini mengalami perubahan yang kurang cepat dan kurang signifikan 
bila dilihat dari site plan awal pembangunannya. Ini menunjukkan kurangnya konsistensi dan komitmen pihak pengembang dalam membangun perumahan Dirgantara Asri.

Namun kondisi fisik infrasruktur tersebut tidak menjadikan warga perumahan menjadi apatis dan berpangku tangan. Kurangnya kepedulian dan tanggungjawab pihak pengembang tidak menyurutkan langkah warga untuk terus membangun lingkungan perumahan menjadi lebih baik. Hal ini diawali dengan upaya membentuk sebuah paguyuban warga perumahan hingga terbentuknya Rukun Tangga (RT). Selain berfungsi sebagai identitas struktural sosial kependudukan, keberadaan lembaga sosial ini juga menjadi wadah bagi warga untuk konsolidasi membangun perumahan.

Konsolidasi ini bisa dilihat dari kegiatan-kegiatan yang secara rutin bisa berjalan dengan baik, seperti pertemuan bulanan, kegiatan Dasawisma/PKK, posyandu, senam sehat, ronda malam, kerja bakti, pengajian ibu-ibu, kegiatan hari-hari besar Islam dan nasional, dsb. Secara swadaya pembangunan lingkungan fisik perumahan juga terus diupayakan warga, mulai dari pembuatan proposal-proposal pembangunan ataupun kegiatan hingga realisasinya. Antusiasme warga sangat besar, didasari oleh harapan-harapan mereka terhadap perubahan lingkungan perumahan yang lebih baik dari waktu ke waktu sebagai kawasan pemukiman yang kondusif. Kemandirian warga perumahan bisa dinilai sangat baik.

Secara demografis, perumahan Dirgantara Asri dihuni oleh warga masyarakat dengan latar belakang sosial, ekonomi, pendidikan, dan agama yang beragam. Hal yang sama juga terlihat pada kelompok usia warga perumahan. Warga perumahan Dirgantara Asri terdiri dari kelompok usia yang lengkap, mulai dari bayi, balita, anak-anak, remaja, pemuda/pemudi, hingga lansia. Faktor demografis ini menjadi faktor yang sangat menentukan dan banyak mempengaruhi dinamika perubahan sosial dan fisik di perumahan. Pada sisi yang lain, faktor ini sebenarnya menjadi faktor yang sangat potensial bagi perkembangan perumahan ke depan.

\section{PERMASALAHAN MITRA}

Dengan segala kondisi yang melingkupinya, sebagai perumahan yang masih butuh pengembangan menjadi lebih baik, perumahan Dirgantara Asri membutuhkan keterlibatan aktif seluruh elemen masyarakat di dalamnya. Selain kolompok usia dewasa dan tua yang berperan utama menjalankan fungsi-fungsi sosial di lingkungan perumahan, kelompok remaja dan atau pemuda/pemudi merupakan elemen yang sangat diperhitungkan. Kelompok ini dipandang sebagai kelompok yang memiliki peran strategis dan penting bagi perumahan. Apalagi mereka juga digadang-gadang sebagai generasi penerus di perumahan. 
Ramey, Lawford, dan Rose-Krasnor (2017) mengungkapkan bahwa partisipasi dalam kemitraan dewasa-pemuda memiliki implikasi signifikan bagi pengembangan dan penghargaan peranan pemuda di dalam masyarakat yang lebih luas. Pengakuan dan pengembangan kontribusi pemuda bisa memiliki konsekuensi-konsekuensi positif, baik bagi pengembangan pemuda maupun bagi masyarakat dan konteks pengembangan lainnya dalam kehidupan mereka.

Demikian pula Head (2010) menyatakan tiga alasan utama bagi patisipasi anak muda. Pertama, anak muda memiliki hak untuk diasuh, dijaga dan diperlakukan dengan hormat, dan bila sesuai dilibatkan dan dibimbing. Kedua, pengembangan pelayanan untuk anak muda membutuhkan supaya pandangan dan minat mereka itu terungkap dan terwujud dengan baik. Ketiga, ada keuntungan-keuntungan pengembangan yang muncul dari partisipasi, bagi para individu mereka sendiri dan bagi masyarakat secara keseluruhan.

Secara tradisional masa remaja dianggap sebagai periode "badai dan tekanan", suatu masa dimana ketegangan emosi meninggi sebagai akibat dari perubahan fisik dan kelenjar. Meningginya emosi terutama karena anak laki-laki dan perempuan berada dibawah tekanan sosial dan menghadapi kondisi baru, sedangkan selama masa kanak-kanak ia kurang mempersiapkan diri untuk menghadapi keadaan-keadaan itu. Tidak semua remaja mengalami masa badai dan tekanan. Namun benar juga bila sebagian besar remaja mengalami ketidak stabilan dari waktu ke waktu sebagai konsekuensi dari usaha penyesuaian diri pada pola prilaku baru dan harapan sosial yang baru (Hurlock, 2002).

Remaja memilih untuk bergabung dalam sebuah kelompok karena mereka beranggapan bahwa menjadi anggota dari sebuah kelompok akan menyenangkan, menarik, dan memenuhi kebutuhan mereka. Remaja juga memiliki kesempatan untuk menerima penghargaan berupa materi maupun psikis (Santrock, 2003). Pada masa remaja, kelompok cenderung terdiri dari anak-anak yang berbeda atau anak-anak yang baru mereka kenal dan berjenis kelamin berbeda. Salah satu kelompok remaja ini adalah organisasi remaja/pemuda. Remaja yang mau ikut serta dalam kelompok tersebut akan tampak lebih mau berpartisipasi dalam kegiatan masyarakat pada masa dewasa mereka dan memiliki harga diri, pendidikan yang lebih tinggi dibanding dengan remaja yang tidak berpartisipasi dalam organisasi kepemudaan (Erikson, 1982).

Keterlibatan remaja dan pemuda di berbagai kegiatan perumahan Dirgantara Asri sudah terlihat menggembirakan dan membanggakan selama ini. Kegiatan-kegiatan sosial seperti perayaan HUT Kemerdekaan RI., senam sehat bersama, hingga pemilihan Ketua RT, melibatkan mereka. Secara organisatoris, remaja dan pemuda perumahan Dirgantara Asri sudah terwadahi dalam organisasi yang diberi nama "Satuan Pemuda - Pemudi Dirgantara Asri 
(SAPDA)" yang baru terbentuk pada tahun 2015 lalu. Mereka memiliki bermacam latar belakang pendidikan, pekerjaan, keluarga, dan agama. Perbedaan latarbelakang ini tidak menjadi halangan bagi mereka untuk bersemangat melaksanakan kegiatan-kegiatan di linkungan perumahan.

Permasalahan yang hingga kini menjadi kegelisahan bersama di perumahan adalah efektifitas SAPDA sebagai organisasi kepemudaan. Hal ini menyangkut masalah kedisiplinan waktu, ketertiban administrasi, soliditas tim, etika bersikap dan bertindak, serta masalahmasalah lain yang bersifat personal dan yang sedikit banyak dipengaruhi faktor orangtua/keluarga. Hal-hal ini menjadi kendala sekaligus tantangan bagi optimalisasi organisasi kepemudaan SAPDA di lingkungan perumahan Dirgantara Asri.

Pengembangan organisasi kepemudaan SAPDA merupakan kebutuhan mendesak yang harus direncanakan dengan baik, matang, dan seimbang. Pengembangan semacam ini diharapkan bisa meningkatkan kualitas keterlibatan pemuda/pemudi anggota SAPDA dalam berbagai agenda kegiatan kemasyarakatan di lingkungan perumahan Dirgantara Asri ke depan. Selain itu, pengembangan juga secara langsung ataupun tidak langsung akan mengokohkan eksistensi SAPDA sebagai organisasi kepemudaan dan elemen sosial yang mewadahi aktualisasi peran pemuda/pemudi dan sekaligus sebagai media dan proses regenerasi di perumahan Dirgantara Asri.

\section{METODE KEGIATAN}

Pengabdi memperhatikan rekomendasi Akiva dan Petrokubi (2016) tentang pentingnya program-program kepemudaan memberikan landasan bagi pemuda untuk mengambil tanggung jawab dan pengaruh pada level yang lebih tinggi dalam masyarakat dan pentingnya peningkatan kapasitas organisasional bagi program-program kegiatan kepemudaan dengan membangun sistem dukungan masyarakat yang luas. Partisipasi dalam program kegiatan kepemudaan yang positif menjadi sumber daya yang penting bagi pemuda untuk mengembangkan kekuatan-kekuatan individu, seperti ketrampilan-ketrampilan penyesuaiandiri dan keselarasan sumber daya-sumber daya program (Mueller, Phelps, Bowers, Agans, Urban, dan Lerner, 2011).

Kegiatan pengabdian masyarakat ini secara garis besar berbentuk pelatihan pengembangan organisasi kepemudaan dengan menggunakan pendekatan-pendekatan psikologis, sosiologis, dan edukatif. Menurut Bennis (Nawawi, 2006), pengembangan organisasi merupakan respon terhadap perubahan yang berhubungan dengan segi pendidikan yang kompleks untuk mengubah keyakinan, sikap, nilai-nilai dan struktur organisasi, agar 
mampu mengadaptasi secara baik teknologi baru, perubahan masyarakat yang dilayani, dan tantangan-tantangan di dalam perubahan yang rumit tersebut.

Pengembangan organisasi semacam itu dapat diadaptasi dengan menyelenggarakan kegiatan pendidikan dan pelatihan. Kegiatan ini harus diselenggarakan melalui anggota organisasi sebagai sumber daya manusia yang dimiliki organisasi. Melalui kegiatan pendidikan dan pelatihan, dengan andragogi yang tepat, diharapkan kondisi kemampuan kerja dan sikap anggota terhadap organisasi akan meningkat (Nawawi, 2006).

Berdasarkan penjelasan tersebut pengabdian masyarakat ini direalisasikan melalui tiga kegiatan, yaitu: focus group discussion (FGD), outbound, dan pelatihan. Melalui kegiatankegiatan ini diharapkan para pemuda dan pemudi di Perumahan Dirgantara Asri, sebagaimana dinyatakan Liang, Spencer, West, dan Rappaport (2013), memiliki rasa agensi dan rasa bertujuan dimana hal itu bisa menimbulkan efek transformatif terhadap perspektif-perspektif pemuda tentang diri mereka sendiri, dari penerima pasif menuju agen-agen perubahan. Artinya, SAPDA sebagai organisasi kepemudaan bisa berperan lebih baik dan meningkat lagi di tengah masyarakat.

Pertama, focus group discussion (FGD). Kegiatan FGD dilakukan sebagai upaya brainstorming untuk membangun self-awareness dan sensitifitas peserta terhadap organisasi, serta mengidentifikasi persoalan-persoalan di dalam organisasi dan motivasi berorganisasi dari peserta. FGD dilakukan dengan membagi peserta ke dalam tiga kelompok berdasarkan status aktivitas utama peserta, yaitu pendidikan dan pekerjaan. Masing-masing kelompok FGD didampingi seorang asisten pengabdian yang berperan sebagai fasilitator (Lampiran 1).

Proses FGD dijalankan dalam suasana rileks tetapi fokus, yang didasari oleh keterbukaan, kejujuran, sikap kritis dan building raport yang baik antara fasilitator dengan peserta. Masing-masing fasilitator menggunakan lembar panduan untuk memimpin diskusi (Lampiran 2). Panduan FGD mengandung dua hal, yakni penjelasan proses diskusi dan daftar pertanyaan yang mencakup topik motivasi berorganisasi (10 pertanyaan) dan persepsi tentang SAPDA (10 pertanyaan). Meski ada panduan FGD, pertanyaan-pertanyaan yang dilontarkan fasilitator bersifat semi terstruktur, atau fleksibel (urutan) dan open-ended (bebas mengalir). Setiap butir pertanyaan dilengkapi dengan kata-kata kunci sebagai driving/probing untuk memperjelas pertanyaan dan mendorong peserta memberikan respon jawaban.

Kedua, outbound. Kegiatan outbond didasarkan pada hasil FGD yang dilakukan sebelumnya. Kegiatan ini dilakukan secara out-door di tanah lapang samping komplek Perumahan Dirgantara Asri. Bentuk permainan outbound yang diikuti peserta bersifat pasangan dan kelompok. Permainan pasangan berupa membawa balon dengan punggung 
belakang kedua peserta dengan melewati rintangan tali dan menusukkan balon ke jarum yang dipasang di garis finish. Adapun permainan kelompok terdiri dari: estafet memindahkan kelereng melalui belahan bambu dan berjalan di atas belahan bambu yang dipindahkan satu persatu hingga mencapai garis finish. Kedua permainan ini diikuti oleh 4 kelompok peserta dan dilombakan agar menarik dan sungguh-sungguh. Pada kegiatan out-door ini semua peserta diuji kesadaran diri, tanggung jawab, kerjasama, komunikasi, kreativitas, dan komitmen mereka untuk mencapai tujuan bersama.

Selain di luar ruangan, outbound juga berlangsung di ruangan balai pertemuan warga Perumahan Dirgantara Asri. Dua permainan yang diikuti peserta bersifat teamwork dan dilakukan dalam waktu yang lebih lama, yaitu sekitar dua jam. Tingkat kesulitan menyelesaikan permainan ini juga lebih besar, sebanding dengan kemampuan teambuilding peserta yang diharapkan muncul lebih besar daripada permainan-permainan sebelumnya. Kemampuan yang dimaksud meliputi: pemahaman terhadap tujuan dan strategi mencapainya; manajemen resiko/tantangan; tanggungjawab; komunikasi/koordinasi; kerjasama/sinergi; dan komitmen individu dan kelompok. .

Dalam kegiatan ini peserta dibagi ke dalam lima kelompok yang masing-masing terdiri dari 3 orang. Permainan pertama adalah membuat menara setinggi-tingginya dan sekokohkokohnya dari sedotan plastik yang dibagikan dalam jumlah dan ukuran yang sama (25 batang per kelompok). Aturan yang berlaku adalah tidak diperbolehkan menggunakan alat bantu atau bahan tambahan apapun dan harus selesai dalam waktu yang relatif singkat (sekitar 30 menit). Permainan ini menguji konsentrasi, kecepatan, kerjasama, sikap saling menghargai, dan kreatifitas peserta. Setelah selesai, semua menara yang dihasilkan diuji tinggi dan kekokohannya dengan cara ditiup dari jarak dekat.

Permainan kedua adalah menjalankan misi penyelamatan telur. Setiap kelompok diberi seperangkat perlengkapan berupa kertas karton, isolatip dan double-tip, gunting, lem kertas, dan 1 butir telur ayam yang sudah diikat menggantung (1,5 meter di atas lantai) di tiap-tiap posisi kelompok peserta. Permainan ini menantang peserta untuk menyelamatkan telur ayam supaya turun ke permukaan lantai tanpa pecah, dengan syarat melewati sirkuit yang dirakit bersama-sama oleh semua anggota kelompok dari bahan dan peralatan yang sudah dibagikan.

Keseluruhan permainan outbond, baik outdoor maupun indoor, dipandu langsung oleh ketua tim pengabdian dan dibantu oleh tiga orang asisten mahasiswa. Setelah rangkaian permainan outbond selesai dilakukan, dengan difasilitasi oleh ketua dan tim pengabdian semua peserta mengikuti sesi refleksi di tempat yang sama untuk mengikat makna dibalik kegiatan outbond. Setiap peserta secara berurutan diberi kesempatan mengungkapkan pelajaran- 
pelajaran penting dari setiap permainan yang telah diikuti. Selanjutnya, fasilitator kemudian menggarisbawahi poin-poin makna utama yang terkandung dalam semua permainan dan merefleksikan arti penting makna tersebut bagi individu anggota SAPDA dan organisasi SAPDA itu sendiri.

Ketiga, pelatihan. Kegiatan pelatihan dirancang berdasarkan temuan hasil FGD serta hasil survey atau pengamatan awal sebelumnya terhadap permasalahan yang dihadapi SAPDA di perumahan Dirgantara Asri. Pelatihan ini sendiri merupakan bagian penguatan terhadap pesan-pesan nilai yang muncul dalam outbound sebelumnya, atau sebagai penegasan atas makna-makna penting yang terkandung dalam kegiatan tersebut. Demikian pula pelatihan mengakomodir permasalahan penting yang terungkap pada saat FGD. Materi pelatihan terfokus pada tujuan dan efektifitas organisasi, yang mencakup penetapan tujuan (goal setting), strategi pencapaian tujuan, analisis SWOT, efektifitas kelompok, konflik dalam kelompok, dan kerjasama.

Penyampaian materi pelatihan dilakukan dengan menggunakan proyektor (LCD) dan screen untuk menampilkan slide-slide presentasi, disamping handout materi yang dibagikan kepada para peserta. Untuk menarik minat dan motivasi peserta, materi juga disampaikan melalui simulasi game (lempar bola ke dalam keranjang) yang mengilustrasikan inti utama materi pelatihan. Para peserta juga mendapatkan paket kelengkapan pelatihan berupa case plastik yang berisi blocknote dan bolpoin untuk mencatat hal-hal penting dari materi. Proses pelatihan dirancang bersifat interaktif dimana peserta mendapatkan kesempatan untuk menanggapi, bertanya, dan berbagi. Dengan rancangan seperti ini, pelatihan diharapkan bisa meningkatkan motivasi peserta, baik motivasi hidup maupun berorganisasi, dan memberikan stimulasi bagi upaya-upaya pengembangan organisasi SAPDA yang lebih kreatif dan progresif di masa-masa mendatang.

\section{HASIL KEGIATAN DAN PEMBAHASAN}

\section{Hasil Kegiatan}

Pelatihan pengembangan organisasi kepemudaan Satuan Pemuda dan Pemudi Dirgantara Asri (SAPDA) dalam kegiatan pengabdian masyarakat ini memperoleh hasil-hasil kegiatan sebagai berikut:

\section{Focus Group Discussion (FGD)}

Kegiatan FGD diikuti oleh 22 orang peserta. Dari 29 peserta yang terdaftar namanya, ada 7 orang yang berhalangan hadir. Peserta yang hadir terbagi ke dalam kelompok-kelompok 
kecil yang dibuat berdasarkan kesamaan latar belakang tingkat pendidikan atau pekerjaan, yaitu kelompok: Pelajar SMP/MTs (6 orang), Pelajar SMU/SMK (9 orang), dan Mahasiswa/Pekerja (7 orang). Masing-masing kelompok FGD dipandu oleh satu orang fasilitator sebagai asisten pengabdian (mahasiswa), yaitu: Nida Urrahma Hidayati (Pelajar SMP/MTs), Putri Candra Kusumaningsih (Pelajar SMU/SMK), dan Muhammad Rifqi Hafizhudin Arif (Mahasiswa/Pekerja).

Kegiatan FGD dilakukan di balai pertemuan warga Perumahan Dirgantara Asri pada hari Sabtu, 25 November 2017, pukul 19.30-22.00 WIB. FGD ini berlangsung dalam suasana santai yang didasari oleh keterbukaan, kejujuran, sikap kritis dan building raport yang baik antara pengabdi dengan peserta kegiatan. Fokus tema dalam kegiatan diskusi ini secara garis besar mencakup tema-tema motivasi berorganisasi, persepsi tentang efektifitas organisasi, dan ekspektasi anggota terhadap organisasi SAPDA.

Sebagai bentuk need assesment FGD ini menemukan beberapa hasil diskusi dari tiga kelompok, yang secara garis besar terdiri dari dua kelompok pernyataan, yaitu motivasi berorganisasi dan persepsi tentang SAPDA.

1. Kelompok FGD A (Pelajar SMP/MTs)

Dari diskusi kelompok ini, ditemukan bahwa pada umumnya peserta memahami organisasi sebagai perkumpulan atau sekumpulan orang. Pengalaman berorganisasi mereka dapatkan di sekolah, organisasi Remaja Islam Masjid Dirgantara Asri (RISMADA), dan SAPDA itu sendiri. Meskipun belum terlalu memahami pentingnya organisasi dan kebutuhan berorganisasi masih kecil, peserta merasakan manfaat organisasi seperti adanya solidaritas. Meskipun orangtua mendukung, ada beberapa faktor yang mempengaruhi semangat peserta dalam berorganisasi, yaitu: kesadaran berorganisasi, partisipasi aktif dalam organisasi, dan sikap-sikap kontra terhadap kegiatan organisasi. Peserta sendiri memiliki cara-cara untuk mengatasi kendala-kendala tersebut, diantaranya adalah kreatifitas mengajak teman-teman yang malas kerja, yakni dengan merangkul dan mendorong kesadaran tentang rasa memiliki terhadap kegiatan organisasi. Namun demikian, peserta masih belum memiliki gambaran tentang rencana berorganisasi di waktu-waktu yang akan datang.

Adapun persepsi peserta terhadap organisasi SAPDA secara umum bersifat positif. Selain persepsi positif ada beberapa pandangan kritis. Bagi mereka, SAPDA berperan dalam mengisi waktu, merekatkan persaudaraan, membuat kekompakan pemuda dan pemudi, dan menjadikan perumahan tambah ramai. Selain itu, sebagai manfaat, SAPDA juga dinilai sebagai pembuat event yang mengakrabkan warga dan menjadikan mereka kompak. Sebagian peserta menilai bahwa organisasi ini menjadi tempat belajar. 
Secara kritis peserta mengungkapkan bahwa ketua SAPDA kurang kerjanya, kegiatan tidak banyak dan tidak berjalan baik, serta tidak sesuai dengan kemauan masyarakat. Hal ini dianggap menyebabkan kemalasan dalam organisasi dan menjauhnya beberapa anggota. Mereka menilai ketua adalah sosok yang paling menentukan dan berpengaruh, baik secara internal maupun eksternal diantara warga perumahan sendiri. Mereka berharap SAPDA akan semakin asyik menyenangkan lagi ke depannya.

\section{Kelompok FGD B (Pelajar SMA/SMK)}

Hasil diskusi dari Kelompok B ini menunjukkan bahwa sebagian peserta memiliki pengalaman mengikuti organisasi di sekolah, yaitu OSIS (Organisasi Siswa Intra Sekolah) dan kegiatan ekstrakurikuler. Adapun sebagian peserta lainnya tidak mengikuti organisasi di sekolah karena alasan capek, tidak ada waktu, dan mager (nyaman). Bagi peserta yang berorganisasi, bertemu banyak orang, menambah wawasan dan melatih keberanian merupakan manfaat yang mereka rasakan.

Tentang SAPDA itu sendiri, secara internal, peserta merasakan kekurang-kompakan dan kurang disiplin waktu, terutama ketika ada acara kumpul bareng. Masalah lain yang diungkapkan adalah regenerasi yang kurang dimana hanya anggota-anggota tertentu saja yang selalu terpilih menjadi pengurus, tidak ada yang menggantikan. Disamping itu, beberapa personel pengurus SAPDA dinilai kurang aktif alias "hilang-hilangan". Adapun secara eksternal, para peserta mengungkapkan tentang kurangnya kepercayaan masyarakat, termasuk pengurus RT, terhadap acara-acara yang dilaksanakan SAPDA, meskipun sebenarnya ketika tiba hari pelaksanaan acara masyarakat mendukung. Hal ini terasa sekali pada saat pencarian dana kegiatan.

Selain adanya beberapa masalah tersebut, para peserta menyatakan bahwa peran SAPDA di tengah masyarakat perumahan sudah banyak dengan kegiatan-kegiatan yang mereka adakan. Harapan peserta dari kelompok ini adalah semoga anggota dan pengurus SAPDA semakin kompak dan mendapat dukungan dari masyarakat. Bagi mereka, organisasi ini bermanfaat sebagai ajang kumpul-kumpul, menambah pengalaman, dan berbagi cerita dengan sesama teman.

\section{Kelompok FGD C (Mahasiswa/Pekerja)}

Dari kelompok peserta yang lebih senior ini, muncul beberapa hasil diskusi. Menurut mereka, organisasi adalah kekompakan, kepekaan, menghargai, kerjasama, saling melengkapi, dari sekelompok orang yang memiliki visi yang sama. Pengalaman berorganisasi yang mereka rasakan terkait dengan kemampuan untuk menyelaraskan, menyatakan, dan bersama-sama. 
Peserta sepakat tentang arti pentingnya organisasi yang begitu besar, karena bermanfaat untuk melatih tanggung jawab dan toleransi.

Meskipun demikian, motivasi berorganisasi mereka sendiri selama ini lebih ditentukan oleh orang lain, belum menjadi motivasi intrinsik. Semangat peserta dalam beroganisasi lebih banyak tergantung pada ajakan teman atau rayuan mereka. Pada sisi lain sebenarya mereka menyadari bahwa pihak-pihak yang mempengaruhi semangat berorganisasi tersebut adalah teman dan orang tua, disamping diri mereka sendiri. Adapun beberapa faktor yang mendorong semangat itu muncul antara lain sikap "koplak" (slengekan), kebersamaan, adanya masalah, dan snack sebagai daya tarik tersendiri.

Berkaitan dengan kendala berorganisasi, peserta menyebutkan sejumlah hal, yakni kurangnya disiplin waktu, watak negatif anggota atau pengurus, sulitnya waktu berkumpul dan adanya "forum dalam forum" dimana fokus anggota terganggu ketika ada suatu pertemuan karena sikap-sikap tidak memperhatikan. Kendala-kendala ini juga yang dianggap menjadi masalah umum dalam SAPDA. Mereka menyatakan bahwa untuk mengatasi kendala-kendala tersebut maka yang dibutuhkan adalah perubahan diri. Salah satu rencana berorganisasi yang mereka ungkapkan adalah mengadakan aksi sosial dan menghidupkan kembali pengumpulan barang-barang bekas milik warga perumahan.

Tentang organisasi SAPDA sendiri, peserta menilai bahwa organisasi ini sudah banyak berperan di tengah masyarakat melalui berbagai kegiatan perumahan, misalnya bakti sosial, pemilihan pengurus RT, syawalan, dan lain-lain. Keterlibatan mereka adalah sebagai pelaksana dan pendukung kegiatan. Sedangkan bagi diri mereka sendiri, manfaat SAPDA antara lain sebagai media bertukar pikiran, memperbanyak kawan, melatih kedisiplinan dan tanggung jawab, meningkatkan ketrampilan public speaking, dan mengasah kepekaan sosial.

Dalam pandangan peserta, faktor SDM, kedisiplinan dan sensitifitas mempengaruhi perjalanan SAPDA selama ini. Menurut mereka masalah SDM menjadi salah satu kekurangan organisasi ini, sedangkan kekompakan merupakan hal positif yang mereka banggakan sebagai kelebihan. Mereka juga menyadari tentang adanya tantangan bagi pengurus ataupun anggota untuk meluangkan waktu demi kepentingan organisasi. Kesadaran lain sebagai autocritic yaitu tentang kekompakan dan soliditas. Kedua hal ini juga menjadi harapan terbesar mereka, agar SAPDA lebih maju lagi ke depannya.

\section{Outbound}

Kegiatan outbond dilaksanakan pada hari Minggu, tanggal 10 Desember 2017, mulai dari pukul 08.30 - 12.30 WIB atau berlangsung sekitar empat jam. Peserta yang mengikuti kegiatan kedua ini berjumlah 15 orang atau setengah dari jumlah seluruh anggota SAPDA. Hal 
ini disebabkan karena pada saat itu rata-rata sebagian dari mereka memiliki acara keluarga atau halangan lain.

Kegiatan outbound dilakukan secara in-door di balai pertemuan warga Perumahan Dirgantara Asri dan secara out-door di tanah lapang dekat komplek perumahan. Kegiatan outbond ini terdiri dari rangkaian permainan berpasangan dan berkelompok. Permainanpermainan outdoor meliputi: berpasangan membawa balon, beregu estafet membawa dan memindahkan kelereng dengan belahan bambu, dan beregu estafet memindah dan berjalan di atas beberapa belahan bambu. Ketiga permainan ini terlaksana di tanah lapang yang ada di samping komplek perumahan. Adapun permainan berkelompok membuat jalur rakitan penyelamatan telur dilakukan di balai pertemuan warga. Bermacam permainan tersebut dirancang mengandung materi tentang nilai-nilai kerjasama, sinergi, komunikasi, tujuan hidup dan kesadaran diri (self-awareness).

Setelah rangkaian permainan outbound selesai dilakukan dan diikuti istirahat serta makan siang, secara bergantian semua peserta mengungkapkan refleksi masing-masing. Berdasarkan refleksi-refleksi tersebut, para peserta menyadari dan menyepakati pentingnya komunikasi, koordinasi, kerjasama, kekompakan, dan kreativitas dalam kerja kelompok untuk mencapai tujuan bersama. Menurut peserta, sikap saling peduli, saling memahami dan menghargai, tolong-menolong, dan tanggap situasi merupakan sikap yang sangat penting dan dibutuhkan ketika melaksanakan agenda kegiatan bersama. Pengabdi di akhir sesi refleksi memberikan catatan-catatan penutup berkaitan dengan makna-makna utama dan penting yang terkandung dalam masing-masing permainan, baik dalam konteks kehidupan individu maupun kehidupan organisasi.

\section{Pelatihan}

Pelatihan ini adalah kegiatan penutup dari rangkaian kegiatan pengabdian masyarakat dengan penerima manfaat organisasi kepemudaan SAPDA. Pelatihan ini dilaksanakan di balai pertemuan warga milik Perumahan Dirgantara Asri. Adapun waktu pelaksanaan kegiatan ini mengambil waktu malam hari, yakni hari Sabtu, tanggal 23 Desember 2017. Pelatihan berlangsung selama kurang lebih tiga jam, mulai dari pukul 19.00 hingga 22.00 WIB, dan diikuti oleh 21 orang peserta.

Pertama-tama kegiatan pelatihan diawali dengan makan malam bersama. Adapun acara utama pelatihan ini dibuka dengan sebuah permainan (lempar bola ke dalam keranjang) sebagai simulasi sekaligus ilustrasi pengantar sebelum memasuki presentasi materi oleh pengabdi. Materi pelatihan terfokus pada: goal setting, strategi merumuskan tujuan, analisis SWOT, konflik dalam kelompok, efektifitas kelompok, kerjasama dalam kelompok, serta sikap 
proaktif dan reaktif. Materi-materi ini dituangkan dalam 12 slide presentasi. Selain itu, materi juga dilengkapi dengan penguatan-penguatan psikologis untuk mengembangan motivasi intrinsik anggota SAPDA dan motivasi kolektif dalam berorganisasi, melalui contoh-contoh konkrit pengalaman atau peristiwa sehari-hari yang dekat dengan kehidupan peserta.

Selain memperhatikan penjelasan materi, para peserta sebagian juga terlihat aktif mencatat hal-hal yang dianggap penting atau menarik, sambil sesekali membaca materi yang juga dibagikan sebagai handout. Mereka memanfaatkan fasilitas pelatihan, seperti bloknote dan ballpoin, yang dikemas dalam satu map plastik.

\section{Pembahasan}

Kegiatan-kegiatan yang dirancang dalam pengabdian ini diharapkan mendorong partisipasi pemuda dan pemudi di lingkugan Perumahan Dirgantara Asri yang lebih aktif dan positif. Partisipasi semacam ini memiliki arti penting dengan alasan bahwa anak muda juga memiliki hak untuk diasuh, dijaga dan diperlakukan dengan hormat, dan serta dilibatkan dan dibimbing. Selain itu, mereka juga butuh dilayani dengan baik supaya pandangan dan minat mereka itu terungkap dan terwujud dengan baik (Head, 2010). Tiga kegiatan pengabdian (FGD, outbond, dan pelatihan) ini dilakukan dalam rangka memenuhi hak-hak dan kebutuhan tersebut.

Pemuda dan pemudi yang tergabung dalam SAPDA merupakan salah satu kelompok sosial yang sedang dalam proses penyesuaian diri terhadap kondisi-kondisi baru dan harapanharapan sosial yang baru juga (Hurlock, 2002). Kegiatan-kegiatan pengabdian disini memberikan kesempatan kepada mereka untuk menerima penghargaan berupa materi maupun psikis (Santrock, 2003), karena ungkapan pandangan dan minat mereka bisa didengar dan direspon dengan baik. Sehingga hal ini akan mendorong mereka lebih mau berpartisipasi dalam kegiatan masyarakat dan memiliki harga diri (Erikson, 1982). Melalui kegiatan pendidikan dan pelatihan bagi anggota SAPDA, maka dengan andragogi yang tepat, kondisi kemampuan kerja dan sikap anggota terhadap organisasi akan meningkat (Nawawi, 2006). Prosedur dari masingmasing kegiatan telah disusun dengan memperhatikan prinsip-prinsip andragogi tersebut.

Kegiatan-kegiatan pengabdian ini sesuai dengan rekomendasi Akiva dan Petrokubi (2016) yang menekankan pentingnya program-program kepemudaan yang mengembangkan tanggung jawab dan pengaruh pemuda dalam masyarakat dan pentingnya peningkatan kapasitas organisasional kepemudaan, dalam hal ini SAPDA. Kegiatan-kegiatan ini juga bernilai positif yang menjadi sumber daya yang penting bagi pemuda untuk mengembangkan kekuatan-kekuatan individu, seperti ketrampilan-ketrampilan penyesuaian-diri dan keselarasan sumber daya-sumber daya program dalam organisasi (Mueller, dkk., 2011). 


\section{KESIMPULAN DAN SARAN}

Secara garis besar, hasil diskusi tentang motivasi berorganisasi menunjukkan bahwa kesadaran berorganisasi, partisipasi aktif, dan sikap-sikap kontra terhadap kegiatan organisasi menjadi kendala umum yang dirasakan peserta. Selain itu adalah kepemimpinan dan kepengurusan SAPDA yang tidak efektif, kekurang-kompakan dan kurang disiplin waktu dipandang sebagai masalah yang mengganggu. Berdasarkan kondisi ini, motivasi berorganisasi mereka lebih bersifat ekstrinsik, yakni lebih banyak ditentukan oleh orang lain (teman-teman dan lingkungan masyarakat setempat).

Adapun persepsi peserta terhadap organisasi SAPDA secara umum bersifat positif sekaligus kritis. Mereka menaruh harapan yang besar pada organisasi ini, yaitu supaya lebih maju dan baik lagi ke depannya. Semua peserta mengakui adanya manfaat SAPDA yang dirasakan, diantaranya mengisi waktu, merekatkan persaudaraan, membuat kekompakan pemuda dan pemudi, menjadikan perumahan tambah ramai, menjadi tempat belajar, menambah wawasan, dan melatih keberanian, tanggung jawab dan toleransi. Meski demikian, peserta sendiri masih belum memiliki gambaran tentang rencana berorganisasi di waktu-waktu yang akan datang.

Adapun kegiatan kedua, yakni outbond, didasarkan pada hasil temuan dalam FGD yang dilakukan sebelumnya. Secara in-door dan out-door, permainan-permainan yang tercakup dalam kegiatan ini umumnya menguji kemampuan dasar dalam team building, seperti: pemahaman terhadap tujuan dan strategi mencapainya, manajemen resiko, tanggungjawab, komunikasi dan koordinasi, kerjasama sinergis, dan komitmen. Sebagai hasil dari kegiatan outbond, refleksi bersama memunculkan suatu kesadaran bersama tentang pentingnya komunikasi, koordinasi, kerjasama, kekompakan, dan kreativitas dalam kerja kelompok untuk mencapai tujuan bersama. Menurut peserta, sikap saling peduli, saling memahami dan menghargai, tolong-menolong, dan tanggap situasi atau kepekaan merupakan sikap yang sangat penting dan dibutuhkan ketika melaksanakan agenda kegiatan bersama.

Sedangkan pelatihan dalam pengabdian ini dirancang berdasarkan temuan hasil FGD serta hasil survey pendahulauan sebagai upaya elaborasi atau refleksi terhadap permasalahan yang dihadapi SAPDA, dan merupakan bentuk penguatan psikologis terhadap pesan-pesan nilai yang disadari bersama dalam outbound. Materi pelatihan terfokus pada tujuan dan efektifitas organisasi, yang mencakup penetapan tujuan (goal setting), strategi pencapaian tujuan, analisis SWOT, efektifitas kelompok, konflik dalam kelompok, dan kerjasama. Pelatihan bertujuan untuk meningkatkan motivasi peserta (individual dan organisasional) guna mendorong perkembangan organisasi kepemudaan SAPDA yang lebih baik. 
Tiga kegiatan pengabdian memenuhi asas keberlanjutan dan berorientasi pada peningkatan efektifitas organisasi SAPDA. FGD mendorong muncunya self-awareness dan sensitifitas peserta terhadap organisasi, kesadaran akan persoalan-persoalan di dalam organisasi dan pentingnya motivasi berorganisasi. Outbound memiliki pengaruh terhadap kesadaran bersama tentang pentingnya kekuatan-kekuatan team building dalam organisasi. Sedangkan pelatihan memberikan penguatan-penguatan psikologis dan menggarisbawahi nilai-nilai utama yang terkandung dalam dua kegiatan sebelumnya.

Berdasarkan hasil dan kesimpulan dari rangkaian kegiatan pengabdian masyarakat ini, maka pengabdi mengajukan beberapa saran sebagai berikut:

Pertama, karakteristik anggota organisasi kepemudaan yang heterogen dan unik dari berbagai latar belakang seperti halnya SAPDA disini merupakan modalitas psiko-sosial yang sangat berharga. Hal utama yang penting dicatat adalah kondisi tersebut memberi ruang bagi proses regenerasi di masyarakat yang lebih luas, dan memberi kesempatan yang berharga sekali untuk saling belajar diantara sesama anggota dan pengurus organisasi.

Kedua, berpijak pada pemahaman itu maka tidak ada hal yang akan sangat diharapkan melainkan dukungan dari masyarakat terhadap keberadaan organisasi kepemudaan SAPDA. Pada satu sisi memang masih dijumpai beberapa kekurangan atau kesalahan, tapi pada sisi yang lain peran SAPDA sangat lah penting dan strategis bagi agenda kegiatan masyarakat perumahan itu sendiri. Hal yang sudah semestinya disadari adalah bahwa SAPDA merupakan organisasi yang masih muda dan sedang dalam tahapan belajar. Persepsi dan harapan yang positif kepada SAPDA tentunya akan lebih baik dikembangkan, apresiasi dan penghargaan atas setiap kontribusi mereka sudah sepatutnya diberikan.

Ketiga, bagi seluruh anggota dan semua pengurus SAPDA, pelajaran utama dari serangkaian kegiatan pelatihan pengembangan organisasi kepemudaan ini tidak lain dan tidak bukan adalah semangat belajar berorganisasi dan semangat mengembangkan organisasi kepemudaan sebagai wahana positif dan kreatif untuk membangun karakter diri dan membangun masyarakat. Berbagai kendala dan tantangan dalam organisasi merupakan bagian dari pengalaman belajar berorganisasi yang niscaya ada dan seharusnya dihadapi secara optimistik, karena berdampak positif bagi peningkatan kedewasaan berpikir, bersikap, dan bertindak.

Keempat, untuk kegiatan serupa yang berorientasi pada pengembangan organisasi kepemudaan, memperhatikan karakteristik peserta itu sangat penting. Alasan utamanya adalah efektifitas kegiatan itu sendiri. Dengan memahami betul karakteristik individual peserta, maka seorang pengabdi akan bisa mempertimbangkan dan merencakan tritment-tritment tertentu 
yang tepat sesuai kebutuhan peserta. Disamping itu, sustainabilitas kegiatan satu dengan kegiatan lain hendaknya dijaga guna mendukung proses internalisasi nilai-nilai utama yang disampaikan kepada peserta melalui kegiatan-kegiatan yang dilaksanakan. Salah satu keterbatasan pengabdian masyarakat ini adalah kurangnya perlakuan yang sesuai dengan individualitas peserta yang memiliki latar belakang heterogen. Sebaiknya masing-masing kelompok peserta yang sudah terklasifikan berdasarkan beberapa latar belakang itu mendapatkan perlakuan yang mengakomodir kebutuhan-kebutuhan mereka secara khusus.

\section{Daftar Pustaka}

Akiva, T., Petrokubi, J. (2016). Growing with youth: A lifewide and lifelong perspective on youth-adult partnership in youth programs. Children and Youth Services Review, 69, 248-258. http://dx.doi.org/10.1016/j.childyouth.2016.08.019

Erickson, J.B. (1982). A profile of community youth organization members, 1980. Boys Town, NE: Boys Town, communication and public division.

Head, B.W. (2010). Why not ask them? Mapping and promoting youth participation. Children and Youth Services Review, 33, 541-547. doi: 10.1016/j.childyouth.2010.05.015

Hurlock, E.B. (2002). Child development. Tokyo: McGraw-Hill Kogakusha Ltd.

Liang, B., Spencer, R., West, J., Rappaport, N. (2013). Expanding the reach of youth mentoring: Partnering with youth for personal growth and social change. Journal of Adolescence, 36, 257-267. http://dx.doi.org/10.1016/j.adolescence.2012.10.002

Mueller, M.K., Phelps, E., Bowers, E.P., Agans, J.P., Urban, J.B., Lerner, R.M. (2011). Youth development program participation and intentional self-regulation skills: Contextual and individual bases of pathways to positive youth development. Journal of Adolescence, 34, 1115-1125. doi:10.1016/j.adolescence.2011.07.010

Nawawi, H. (2006). Kepemimpinan mengefektifkan organisasi. Yogyakarta: Gadjah Mada Universitas Press.

Ramey, H.L., Lawford, H.L., Rose-Krasnor, L. (2017). Doing for others: Youth's contributing behaviors and psychological engagement in youth-adult partnerships. Journal of Adolescence, 55, 129-138. http://dx.doi.org/10.1016/j.adolescence.2017.01.001

Santrock, John W. (2003). Adolescence. Terjemahan Aledar dan Saragih. Jakarta: Erlangga

Lampiran 1: Pembagian Kelompok FGD

Tabel 1. Kelompok FGD A (Pelajar SMP/MTs)

\begin{tabular}{|c|l|c|}
\hline NO & \multicolumn{1}{|c|}{ NAMA } & STATUS \\
\hline 1 & Shinta Putri Riona Rahmawati & MTs \\
\hline 2 & Sani Sinta Nariswari & SMP \\
\hline 3 & Reva Indra Saputra & SMP \\
\hline 4 & Reinzi Aldendi Pramadito & SMP \\
\hline 5 & Muh. Hafidz Ady Khoiri & SMP \\
\hline 6 & Nabila Tafia Atikah & SMP \\
\hline 7 & Moch. Farid Al-Ghozali & SMP \\
\hline 8 & Moh. Bagus Abi Setyawan & SMP \\
\hline 9 & Galudra Pasaka Nirwikara & SMP \\
\hline \multicolumn{2}{|c|}{ Fasilitator: Nida Urrahma Hidayati } \\
\hline
\end{tabular}


Tabel 2. Kelompok FGD B (Pelajar SMU/SMK)

\begin{tabular}{|c|l|c|}
\hline NO & \multicolumn{1}{|c|}{ NAMA } & STATUS \\
\hline 1 & Ajeng Putri Mahadika & SMA \\
\hline 2 & Tika Puspitasari & SMA \\
\hline 3 & Annisa Caturiani Nurfaida & SMK \\
\hline 4 & Desheyla Nurfadhilah & SMK \\
\hline 5 & Hanif Wian Pratama & SMK \\
\hline 6 & Moh. Maulana Afrinullah & SMK \\
\hline 7 & Nanda Septia Nur'Aisyah & SMK \\
\hline 8 & Putri Febriana & SMK \\
\hline 9 & Reno Alfa Karisma Putra & SMK \\
\hline 10 & Riski Adi Novanto & SMK \\
\hline 11 & Salsa Guspita & SMK \\
\hline \multicolumn{2}{|c|}{ Fasilitator: Putri Candra Kusumaningsih } \\
\hline
\end{tabular}

Tabel 3. Kelompok FGD C (Mahasiswa/Pekerja)

\begin{tabular}{|c|l|c|}
\hline NO & \multicolumn{1}{|c|}{ NAMA } & STATUS \\
\hline 1 & Apriliana Puspitasari & Mahasiswi \\
\hline 2 & Fanny Pradhita Nuridha & Mahasiswi \\
\hline 3 & Fauziatun Nisa' & Mahasiswi \\
\hline 4 & Rakhmah Fajrien Anastitania & Mahasiswa \\
\hline 5 & Stefanus Dwi Muryanto & Mahasiswa \\
\hline 6 & Stefanus Nur Dwi Sapto & Bekerja \\
\hline 7 & Shalahudin Al'Ayyuby & Bekerja \\
\hline 8 & Nanda Adi Pratama & Bekerja \\
\hline 9 & Albertus Dian Nova & Bekerja \\
\hline \multicolumn{2}{|c|}{ Fasilitator: Muhammad Rifqi Hafizhudin Arif } \\
\hline
\end{tabular}

Lampiran 2: Panduan Focused Group Discussion

\author{
PANDUAN FOCUSED GROUP DISCUSSION \\ PELATIHAN PENGEMBANGAN ORGANISASI KEPEMUDAAN \\ SATUAN PEMUDA DAN PEMUDI DIRGANTARA ASRI (SAPDA)
}

\title{
PROSES DISKUSI:
}

1. Diskusi terfokus pada motivasi berorganisasi dan persepsi tentang SAPDA.

2. Pertanyaan-pertanyaan bersifat terbuka (open-ended), bila perlu disertai dorongan dan/atau pendalaman untuk memperjelas.

3. Urutan pertanyaan diskusi terpandu secara sistematis.

4. Diskusi berjalan secara informal, penuh keakraban, sharing aktif dan terbuka.

5. Poin-poin utama jawaban peserta tercatat dalam lembar instrumen diskusi.

\section{PERTANYAAN DISKUSI:}

A. Motivasi Berorganisasi

1. Apa itu organisasi menurut Anda?

(drive/probing: teori, asumsi, kegiatan, sifat, dsb.)

2. Bagaimana pengalaman Anda berorganisasi selama ini? (drive/probing: sekolah, kampus, komunitas, masyarakat)

3. Apa sebenarnya arti penting organisasi itu bagi Anda? 
(drive/probing: cita-cita, harapan, pekerjaan, akademik)

4. Apa manfaat yang telah Anda rasakan dengan mengikuti organisasi? (drive/probing: kepribadian, pekerjaan, belajar, masa depan, dll.)

5. Seberapa besar keinginan atau kebutuhan Anda mengikuti organisasi? (drive/probing: besar, sedang, kecil, penting, mendesak, antara butuh-tidak butuh)

6. Siapakah pihak-pihak yang mendukung/menghambat Anda dalam berorganisasi? (drive/probing: orangtua, saudara, teman, guru, dosen, pimpinan, orang lain)

7. Faktor-faktor apakah yang mempengaruhi semangat Anda dalam berorganisasi? (drive/probing: keluarga, sekolah, masyarakat dewasa, pergaulan sosial, lingkungan)

8. Adakah kendala tertentu yang Anda hadapi dalam berorganisasi selama ini? (drive/probing: waktu, fisik, mental, diri sendiri, orang lain, lingkungan)

9. Bagaimana cara Anda mengatasi kendala-kendala yang ada? (drive/probing: manajemen, strategi, teknik, kreatifitas, bantuan, dukungan)

10. Apa rencana Anda dalam berorganisasi di waktu-waktu yang akan datang? (drive/probing: sikap, tindakan, langkah-langkah, upaya)

B. Persepsi tentang SAPDA

1. Bagaimana peran SAPDA selama ini? (drive/probing: acara, kegiatan, partisipasi, agenda, dsb.)

2. Apa manfaat SAPDA bagi masyarakat? (drive/probing: pelaksana, pendamping, pendukung, pelengkap)

3. Apa manfaat SAPDA bagi diri Anda sendiri? (drive/probing: pribadi, sosial, belajar, pekerjaan)

4. Apa masalah umum yang biasa terjadi selama ini? (drive/probing: kepengurusan, keterlibatan, keanggotaan, eksternal)

5. Apa hal-hal yang mempengaruhi perjalanan SAPDA? (drive/probing: kepengurusan, dukungan masyarakat, sumber daya, dll.)

6. Apa kelebihan yang dimiliki SAPDA menurut Anda? (drive/probing: kepengurusan, program, sumber daya, dll.)

7. Apa kekurangan yang dimiliki SAPDA menurut Anda? (drive/probing: kepengurusan, program, sumber daya, dll.)

8. Apa tantangan yang dihadapi SAPDA ke depan? (drive/probing: sumber daya, kepengurusan, kegiatan, dukungan, keterlibatan, dsb.)

9. Apa kritik dan saran Anda untuk kemajuan SAPDA? (drive/probing: sumber daya, kepengurusan, kegiatan, dukungan, keterlibatan, dsb.)

10. Apa harapan terbesar Anda terhadap SAPDA? (drive/probing: sumber daya, kepengurusan, kegiatan, dukungan, keterlibatan, dsb.) 